\title{
KONTROLING RADNIH STROJEVA PRI IZVOĐENJU ŠUMSKIH RADOVA
}

\section{CONTROLLING OF MACHINERY IN PERFORMING FOREST WORKS}

\author{
Branko SITAŠ ${ }^{1}$
}

\section{SAŽETAK}

Kontroling radnih strojeva pri izvođenju šumskih radova predstavlja razvoj sustava upravljanja poslovanjem, nadzor radnog vremena radnih strojeva, analizu prikupljenih podataka, kao podlogu za donošenje poslovnih odluka. Navedeni je sustav povezan sa drugim informatičkim sustavima (različitih poslovnih namjena) koji se rabe u trgovačkom društvu "Hrvatske šume" d.o.o., tvrtki koja gospodari državnim šumama. Prikazani financijski i naturalni izvještaji ponajprije se odnose za strojeve u šumarstvu i predstavljaju suvremeni poslovni model upravljanja u operativnom šumarstvu.

Glavni instrument kontrolinga radnih strojeva je web aplikacija HsKPR. Aplikacija je kontrolni mehanizam praćenja aktivnosti po mjestu troška, što znači za svaki radni stroj u djelatnostima mehanizacije, građevinarstva i osobnog prijevoza. Svaki radni stroj mjesto je troška i prihoda, a svako putničko vozilo mjesto je troška. Aplikacija pruža informacije o planiranim i izvršenim prihodima, rashodima i dobiti radnog stroja. Kod rashoda prate se troškovi goriva, maziva, rezervnih dijelova, guma, internih i eksternih usluga održavanja, amortizacije, plaća strojara. Osim financijskih izvještaja o prihodima, rashodima i dobiti, aplikacija pruža i naturalne pokazatelje o produktivnosti, pogonskim satima, iskoristivosti radnog vremena, potrošnji goriva, praznom hodu i zastojima. Posebno su korisne informacije o troškovima po strojodanu i ostvarenim troškovima po jedinici mjere $\mathrm{kn} / \mathrm{m}^{3}$. Financijski i naturalni izvještaji dostupni su na razini mjesta troška i prihoda, grupe mjesta troška i prihoda te profitnog centra. Grupe mjesta troška i prihoda radni su strojevi iste tehnologije, npr. zglobni šumski traktori, forvarderi, žičare. Profitni centar je djelatnost mehanizacije s poddjelatnostima privlačenja, prijevoza i ostalih sredstava rada te djelatnost građevinarstva s poddjelatnostima radnih strojeva i prijevoza. Svi ti izvještaji dostupni su i na tri organizacijske razine: šumarija odnosno radna jedinica, uprava šuma i trgovačko društvo.

Kontroling izvješća čine podlogu za menadžerske odluke, signal za uzbunu kada ukazuju na značajne nepovoljne razlike između planiranih i ostvarenih pokazatelja, podloga za otkrivanje razloga odstupanja od planiranih zadataka i podloga za propisivanje potrebnih aktivnosti koje vode do ciljanog rezultata.

KLJUČNE RIJEČI: kontroling, strojevi u šumarstvu, plan i analiza, management

\section{KONTROLING U POSLOVANJU CONTROLLING IN BUSINESS ACTIVITY}

Kontroling je stručna funkcija koja pomaže poslovodstvu, ali i svim drugim funkcijama u poduzeću u internom upravljanju s ciljem povećanja produktivnosti, rentabilnosti i ekonomičnosti. Kontroling u gospodarenju šumama predstavlja novu poslovnu funkciju koja osigurava transparentnost financijskih informacija i naturalnih pokazatelja te uz pomoć izvješća poslovodstvu pridonosi većoj učinkovitosti upravljanja. Preduvjet kvalitetnim poslovnim odlukama su egzaktni pokazatelji, odnosno informacije koji proizlaze iz ogromne količine internih podataka o učincima, 
ulaznim troškovima te efektivnim radnim satima. Ti pokazatelji predstavljaju podlogu i polazište poslovodstvu za učinkovito i uspješno upravljanje prema planiranom cilju poslovanja. Poslovno odlučivanje u znatnoj mjeri može utjecati na očekivane planirane rezultate, strukturu organizacije te odgovornost zaposlenika na svim razinama.

„Kontroling je desna ruka i podrška menadžmentu, kojemu je osnovni zadatak ostvariti poslovni cilj. Da bi se to postiglo, potrebno je planirati svaki poslovni korak, svaku poslovnu fazu, svaku poslovnu aktivnost, a da bi sve to funkcioniralo, pobrinut će se kontroling."

Francuski teoretičar menadžmenta Henri Fayol u svojoj knjizi General and Industrial Management definirao je pet osnovnih funkcija menadžmenta:

1. Planning (planiranje)

2. Organizing (organiziranje)

3. Commanding (zapovijedanje, vođenje)

4. Coordinating (koordiniranje aktivnosti)

5. Controlling, što u prijevodu znači mogućnost usmjeravanja ili nadziranja sa svrhom da se sve odvija po planu

Kontroling je poslovna funkcija koja ima ponavljajuće aktivnosti i započinje (P) planiranjem i postavljanjem ciljeva. U sljedećim fazama $(\mathrm{K})$ kontrolira poslovne rezultate i poslovne procese te priprema izvješća za odlučivanje, (K) korigira upravljanje resursima poduzeća $\mathrm{i}(\mathrm{P})$ primjenjuje poslovne odluke za postizanje planiranih ciljeva.

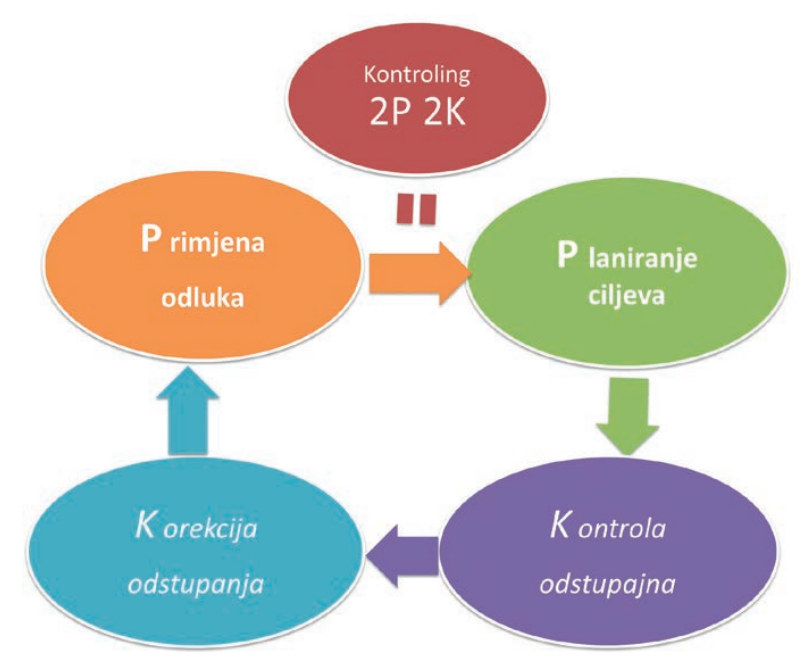

Kontroling kao neizostavna navigatorska i inovatorska podrška u poslovanju, svojom cikličkom aktivnošću osigurava konkurentsku prednost i povećava vrijednost poslovnog subjekta.

\section{KONTROLING PROIZVODNJE - APLIKACIJA HSKPR \\ CONTROLLING OF PRODUCTION - APPLICATION OF HSKPR}

Kontroling radnih strojeva i vozila predstavlja samo jedan segment kontrolinga u gospodarenju šumama, pri čemu je raščlanjen na razinu obveza nižeg, srednjeg i višeg poslovodstva. Svi elementi praćenja vidljivi su na tim razinama. Kontroling radnih strojeva pri izvođenju šumskih radova rezultat je primijenjenih i provjerenih znanja koja u praksi uspješno funkcioniraju. Za uspostavu poslovne funkcije kontrolinga neophodno je poznavanje sustava, „KnowHow", vještine i timski rad u poslovima planiranja i izvještavanja o financijskim i naturalnim pokazateljima strojeva na poslovima sječe, privlačenja i prijevoza drvnih sortimenata. Ovim stručnim člankom želi se pridonijeti povećanju stupanja korisnosti kontrolinga u šumarstvu.

Najkvalitetnije informacije koje proizlaze iz sustava izvješćivanja te njihovo tumačenje trebaju predstavljati temelj upravljanja poslovanjem. Vrhunski profesionalni strojevi nisu jamstvo uspješnog poslovanja. Informacije o učinkovitosti, profitabilnosti i ekonomičnosti tih strojeva važni su čimbenici za postizanje planiranih ciljeva. Navedene informacije moraju biti vizualno dostupne te su prikazane u web aplikaciji Kontroling proizvodnje.

Tvrtka Hrvatske šume d.o.o. u svom sastavu ima 262 organizacijske jedinice, koje posjeduju 5.048 radna stroja za sječu, privlačenje, izvoženje, prijevoz i iveranje, 193 radna stroja i kamiona u građevinarstvu te 1.472 vozila za osobni prijevoz.

Kontroling proizvodnje ima razmjerno dugu tradiciju primjene u Hrvatskim šumama. Poslovna aplikacija HsKpr datira iz 1995. godine i do danas se različito primjenjivala i koristila po podružnicama u obliku mjesečnih izvještaja. Prvotna aplikacija rađena je u programskom jeziku Fox-Pro i predstavlja zastarjelu DOS aplikaciju.

Od 2015. godine uvodi se obveza praćenja kontrolinga proizvodnje u svim organizacijskim jedinicama Hrvatskih šuma za djelatnosti mehanizacije i građevinarstva te vozila za osobni prijevoz pri stručnim službama. Aplikacija se nadograđivala i razvijala, povezala se s drugim aplikacijama unutar tvrtke na način da se podaci informatički prenose iz poslovnih aplikacija u web-aplikaciju Kontroling proizvodnje (HsKpr) (slika 1).

Iz slike je vidljivo da je Kontroling proizvodnje (web aplikacija HsKpr) stavljena u središte zbivanja, jer iz ostalih aplikacija prikuplja većinu financijskih i naturalnih pokazatelja neophodnih za informiranje poslovodstva i izvršenje 


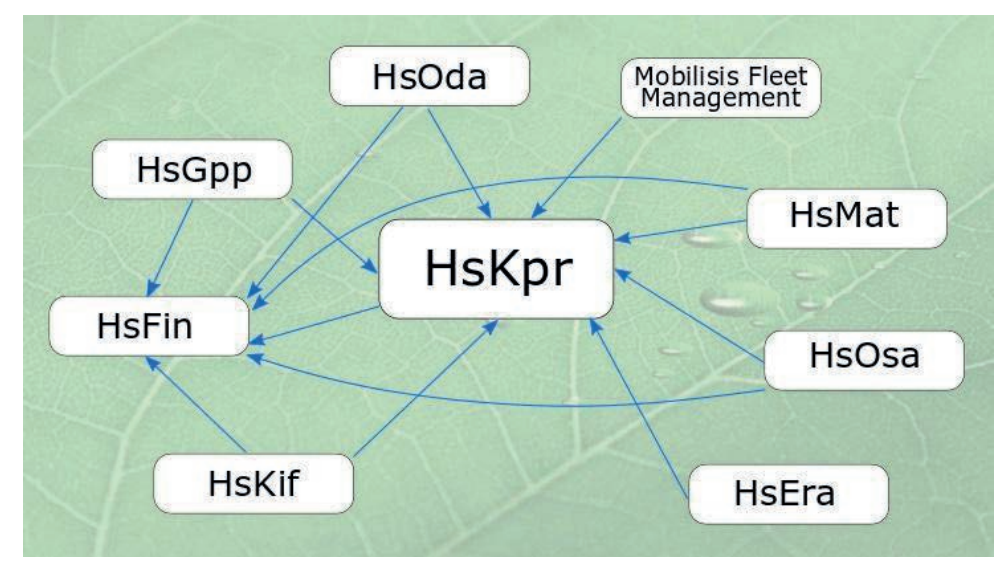

Slika 1. Interakcija i povezanost aplikacije Kontroling proizvodnje s drugim poslovnim aplikacijama u Hrvatskim šumama d.0.0. Figure 1 Interaction and connection of Controlling production application with other business applications in Croatian forests Ltd.

postavljenih ciljeva. Kontroling proizvodnje objedinjuje poslovno planiranje (aplikacija HsGpp), proizvodnju drvnih sortimenata (aplikacija HsPro), račun dobiti i gubitka (aplikacija HsFin), obračun plaća (aplikacija HsOda), evidenciju osnovnih sredstava (aplikacija HsOsa), materijalno poslovanje (aplikacija HsMat), evidenciju računa (aplikacija HsEra), sustav nadzora i praćenje voznog parka (aplikacija Mobilisis Fleet Management) uz podršku prijenosa GPS signala Hrvatskog Telekoma.

Godišnji plan poslovanja (aplikacija HsGpp) u kojemu su određeni naturalni i financijski pokazatelji te ciljevi koje tvrtka treba ostvariti u poslovnoj godini na svim razinama upravljanja, treba biti početna točka kontrolinga. Planiranje i kontroling poslovne su funkcije koje ne idu jedna bez druge. „Planiranje je gledanje prema budućnosti, a kako se odluke ne donose o prošlosti, planiranje je u stvari donošenje odluka. Provođenje odluka u djelo daje nam povratnu informaciju koja je nužna kako bismo potvrdili jesu li odluke uopće bile provedive. To je proces kontrolinga ${ }^{\text {“3 }}$

U web aplikaciju HsKPR prenose se financijski i naturalni podaci iz Plana poslovanja za sva planirana mjesta troška i prihoda. Djelatnost Mehanizacije ima sljedeće grupe mjesta troška i prihoda: motorne pile, adaptirani i zglobni šumski traktori za privlačenje, forvarderi i ekipaže za izvoženje, žičare, harvesteri za sječu i izradu, kamioni za prijevoz trupaca, iverači, poljoprivredni traktori za uzgajanje šuma, traktorski priključci za uzgoj, zaštitu šuma i rasadničarstvo. Djelatnost građevinarstva ima grupe mjesta troška i prihoda: bageri, buldožeri, grejderi, rovokopači, utovarivači, valjci, kompresori, bušače garniture, drobilice, cisterne, kamioni za rasuti teret te prikolice. Vozila za prijevoz zaposlenika imaju ove grupe mjesta troška: autobusi, kombibusi, dostavna vozila, terenska vozila, osobna vozila, mopedi, plovila.
Slijedom slike 1, nakon mjesečnog obračuna plaća, iz aplikacije za obračun plaća HsOda, obavlja se informatički prijenos troškova osoblja. Osim financijskih, prenosi se i dio naturalnih podataka (radni dani proizvodnih radnika).

Iz aplikacije HsMat koja predstavlja materijalno (skladišno) poslovanje prenose se svi materijali i rezervni dijelovi po stavkama te pripadajućim kontima na mjesto troška i prihoda (radni stroj) i mjesto troška (vozilo za osobni prijevoz).

Knjigovodstvo osnovnih sredstava (aplikacija HsOsa) sadrži amortizacije koja se automatski prenosi za svako osnovno sredstvo i djelatnost.

U aplikaciji HsEra (evidencija računa) unose se sve ulazne fakture, a za troškove se određuje mjesto i konto troška koji se automatski prenose u HsKPR. Još nije dorađen automatski prijenos za izlazne račune koji se rade u aplikaciji HsKif, ali postoji idejno rješenje koje čeka provedbu.

Sustav nadzora i upravljanja voznim parkom te informacijama koje su povezane s praćenjem rada strojeva Mobilisis Fleet Management, predstavlja dodatnu podršku kontrolingu proizvodnje. Na taj način jednostavnije se upravlja vlastitim voznim parkom i štede resursi koji proizlaze korištenjem voznog parka. Kontrola potrošnje goriva, evidencija pogonskih radnih sati motora, evidencija kretanja voznog parka, alarmiranje i upozoravanje na nepravilnosti u radu i krađe. Međusobni odnos pogonskih sati rada motora i obračunatih sati rada strojara dobar je pokazatelj kontrole radnog vremena, a prikazan je u web aplikaciji HsKPR.

Sustav nadzora i upravljanja voznim parkom prikuplja informacije o vozilu te njegovom korištenju, kretanju i radu putem ugrađenog uređaja (mobilna jedinica). Uređaj prikuplja informacije o trenutnoj poziciji, brzini kretanja, prijeđenom putu vozila i slično (putem GPS modula). Putem GSM/GPRS veze Hrvatskog Telekoma, odnosno M2M SIM 
kartice, uređaj te podatke o korištenju vozila prenosi na centralno računalo (server), na kojemu se pohranjuju baze podataka o vozilima te svim drugim podacima iz uređaja. Podaci o korištenju voznog parka prezentiraju se u realnom vremenu u aplikativnom rješenju (Internet aplikaciji) na računalu ili mobilnom telefonu/tabletu.

\section{IZVJEŠTAJI IZ WEB APLIKACIJE KONTROLING PROIZVODNJE REPORTS FROM PRODUCTION CONTROLLING WEB APPLICATION}

Financijski i naturalni izvještaji u aplikaciji HsKPR imaju zaista važnu ulogu za poslovodstvo. Kako bi zadovoljili kontinuirane zahtjeve poslovodstva za racionalizacijom i optimizacijom poslovanja, neophodna su ažurna i kvalitetna izvješća kao podloga za donošenje odluka. Izvještaji se ge- neriraju sukladno željenim odnosno odabranim parametrima za razdoblje (godina, mjesec). Vidi sliku 2 i 3.

Izvještaji imaju tri razine izvještavanja. Najniža razina izvještaja je mjesto troška i prihoda (naziv stroja ili inventurni broj) i mjesto troška (naziv putničkog vozila ili inventurni broj). Srednja razina izvještaj je grupa mjesta troška i prihoda iste tehnologije (zglobni šumski traktori, forvarderi, harvesteri, iverači, kamioni itd) i grupa mjesta troška (minibusi, kamioneti, kombibusi do 20 sjedišta, kombibusi 9 sjedišta, osobni automobili, terenski automobili). Djelatnost mehanizacije profitni je centar najviše razine izvješćivanja i ima svoje poddjelatnosti privlačenje, prijevoz i ostala sredstva rada koje su također profitni centri. Djelatnost građevinarstva ima svoje poddjelatnosti radni strojevi i prijevozi. Sve navedeni izvještaji dostupni su za tri organizacijske razine (šumarija, uprava šuma, trgovačko društvo).

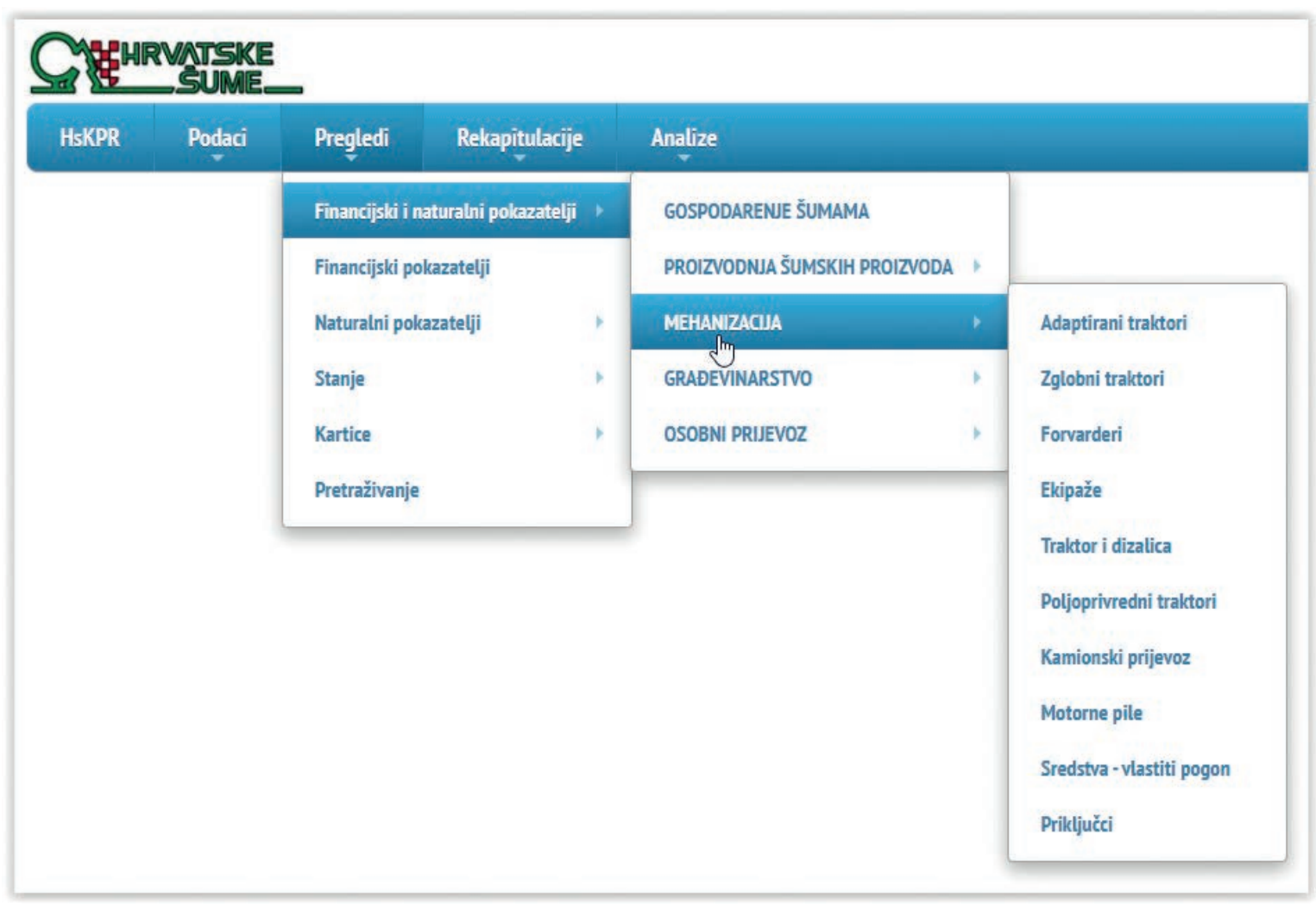

Slika 2. Osnovno sučelje WEB preglednika kontroling radnih strojeva u djelatnosti mehanizacije Figure 2 Basic interface of WEB browser of working machines controlling in mechanization service

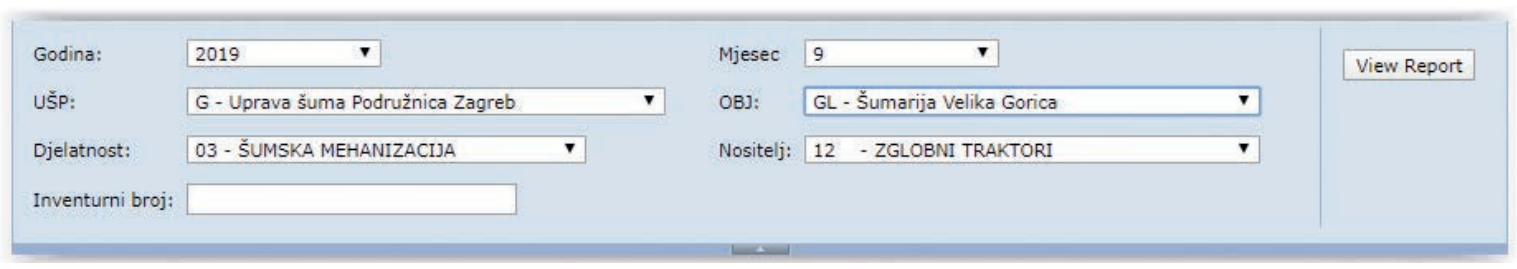

Slika 3. Izbornici za generiranje financijskih i naturalnih izvještaja

Figure 3 Menu for generating financial and non-financial reports 
Izvještaji iz web preglednika kontroling proizvodnje ažuriraju se jednom mjesečno nakon završenog obračuna za protekli mjesec. Ona su dostupna svim internim korisnicima na svim razinama upravljanja i u svim organizacijskim jedinicama.

\section{Financijski izvještaji - Financial reports}

Financijski izvještaji prikazuju planirane i ostvarene prihode, rashode za gorivo, mazivo, rezervne dijelove, gume, interne i eksterne usluge održavanja, osiguranje i registraciju, amortizaciju, plaće strojara te ostvareni financijski rezultat za zadano razdoblje. Iz tih podataka iščitava se rentabilnosti i ekonomičnost svakog stroja kao pokazatelji ukupne uspješnosti poslovanja. Tablica 1. prikazuje financijski izvještaj za zglobni šumski traktor Ecotrak $120 \mathrm{VD}$

Zglobni šumski traktor Ecotrak120 VD u šumariji Senj za razdoblje 1.-12. 2019. godine, inventurni broj 676375 ostvario je pozitivan financijski rezultat u iznosu 90.104 kn. Prihodi su ostvareni sukladno planu u iznosu 399.537 $\mathrm{kn}$, a rashodi $84 \%$ u odnosu na planirano (309.433 kn). Troškovi plaća strojara ostvareni su sa $97 \%$ (124.282 kn), goriva $42 \%$ (30.120 kn), maziva 3\% (256 kn), rezervni dijelovi 38\% (10.056 kn), trošak guma $51 \%(3.659 \mathrm{kn})$, eksterne troškovi održavanja $95 \%$ (24.300 kn), amortizacija $102 \%$ (104.347 kn) u odnosu na plan. Dobit je 3 puta veće od plana (90.104 kn). Glavni razlog boljeg izvršenja dobiti u odnosu na planirano leži u činjenici da su ostva-

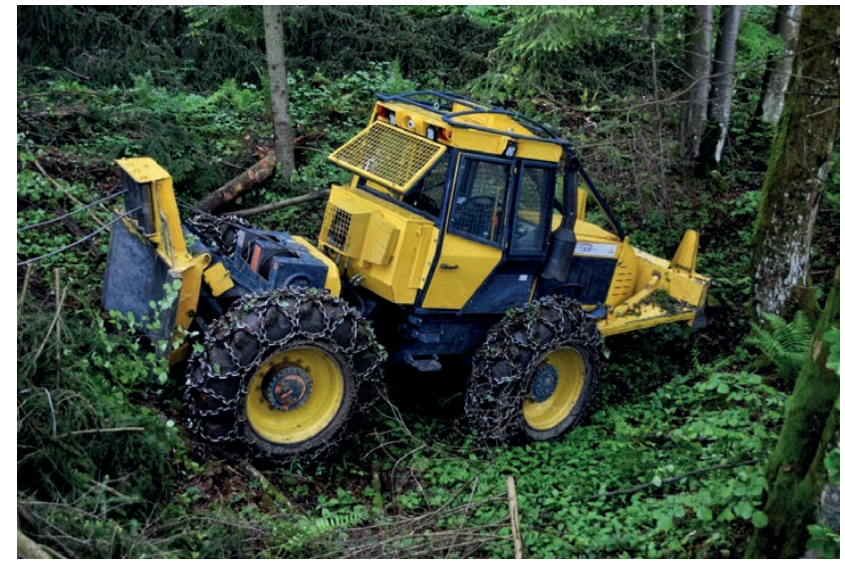

reni manji rashodi u odnosu na planirane. Izvršeni rashodi su niži od planiranih i ukazuju na nužnu izmjenu planiranih rashoda u kalkulaciji stroja.

\section{Naturalni izvještaji - Non-financial reports}

Naturalni izvještaji prikazuju proizvodnost kao mjerilo uspješnosti poslovanja radnog stroja. Prikazani su ukupna potrošnju goriva, izvršeni $\mathrm{m}^{3}$, radni sati za rad u normi i rad po vremenu, neproduktivni radni sati, zastoji, rezultati potrošnje goriva $1 / \mathrm{m}^{3}$, potrošnje goriva po radnom satu i pogonskom satu, učinkovitost $\mathrm{m}^{3} /$ danu (8 sati), trošak po jedinici proizvoda $\mathrm{kn} / \mathrm{m}^{3} \mathrm{i} \mathrm{kn} / \mathrm{radnom}$ satu. Tablica 2. prikazuje naturalni izvještaj za zglobni šumski traktor Ecotrak 120 VD.

Tablica 1: Pregled financijskih pokazatelja za zglobni šumski traktor Ecotrak 120 VD Table 1: Overview of financial indicators for skidder Ecotrack 120 VD

\begin{tabular}{|c|c|c|c|c|c|c|c|c|c|c|c|c|c|c|c|c|}
\hline \multicolumn{3}{|c|}{$\begin{array}{l}\text { UPRAVA ŠUMA PODRUŽNICA SENJ } \\
\text { FORESTRY BRANCH OFFICE SENJ }\end{array}$} & \multicolumn{14}{|c|}{ PREGLED FINANCIJSKIH POKAZATEUA $\quad 01.01 .2019 .-31.12 .2019}$. \\
\hline \multicolumn{17}{|c|}{ ŠUMARIJA SENJ } \\
\hline \multicolumn{17}{|l|}{ FORESTRY UNIT } \\
\hline \multicolumn{17}{|l|}{ SENJ } \\
\hline \multirow[b]{2}{*}{$\begin{array}{l}\text { Mjesto troška i } \\
\text { prihoda }\end{array}$} & \multirow[b]{2}{*}{$\begin{array}{l}\text { Vrsta sredstva, } \\
\text { inventurni broj, } \\
\text { godina proizvodnje }\end{array}$} & \multicolumn{13}{|c|}{ Troškovi / Costs } & \multirow[b]{2}{*}{ PRIHODI } & \multirow[b]{2}{*}{ DOBIT } \\
\hline & & & $\begin{array}{l}\text { Broj sredstava } \\
\text { prema satima rada }\end{array}$ & Gorivo & Mazivo & $\begin{array}{l}\text { Rezervni } \\
\text { dijelovi }\end{array}$ & Gume & $\begin{array}{l}\text { Usluge } \\
\text { održavanja } \\
\text { eksterne }\end{array}$ & $\begin{array}{l}\text { Usluge } \\
\text { održavanja } \\
\text { interne }\end{array}$ & $\begin{array}{l}\text { Osiguranje } \\
\text { registracija }\end{array}$ & Amortizacija & Plaće & Ostalo & UKUPNO & & \\
\hline $\begin{array}{l}\text { Cost and } \\
\text { Revenue Center }\end{array}$ & \begin{tabular}{|l} 
Type of \\
machine, inventory \\
number, year of \\
manufacture
\end{tabular} & & \begin{tabular}{|l|} 
Number of \\
machines according \\
to operating hours
\end{tabular} & Fuel & oil & $\begin{array}{l}\text { Spare } \\
\text { parts }\end{array}$ & Tires & $\begin{array}{l}\text { Maintenance } \\
\text { services } \\
\text { external }\end{array}$ & $\begin{array}{l}\text { Maintenance } \\
\text { services } \\
\text { internal }\end{array}$ & $\begin{array}{l}\text { Insurance and } \\
\text { registration } \\
\text { costs }\end{array}$ & Amortization & Salary & other & TOTAL & REVENUE & PROFIT \\
\hline \multirow{3}{*}{1212} & \multirow{3}{*}{$\begin{array}{l}\text { ZŠT ECOTRAC } 120 \\
\text { VD, 676375, } 2016 . \\
\text { god. }\end{array}$} & Plan & 1,00 & 71.190 & 7.119 & 26.408 & 7.167 & 25.688 & 0 & 0 & 102.750 & 128.519 & 0 & 368.840 & 398.880 & 30.040 \\
\hline & & Realization & 1,00 & 30.120 & 256 & 10.056 & 3.659 & 24.300 & 0 & 1.697 & 104.347 & 124.282 & 10.717 & 309.433 & 399.537 & 90.104 \\
\hline & & $\%$ & 100,00 & 42,31 & 3,59 & 38,08 & 51,05 & 94,60 & 0,00 & 0,00 & 101,55 & 96,70 & 0,00 & 83,89 & 100,16 & 299,94 \\
\hline
\end{tabular}

Tablica 2: Pregled naturalnih pokazatelja za zglobni šumski traktor Ecotrak 120 VD Table 2: Overview of non-financial indicators for skidder Ecotrack 120 VD

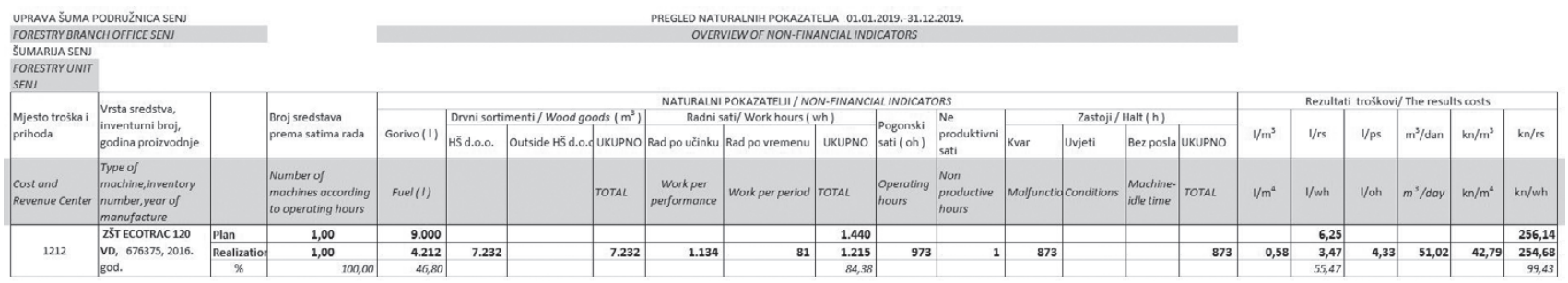


Zglobni šumski traktor Ecotrak 120 VD u šumariji Senj za razdoblje 1.-12. 2019. godine, inventurni broj 676375 privukao je $7.323 \mathrm{~m}^{3}$ drvnih sortimenata za 1.134 radnih sati. Pomoćni radovi poput izrada izlaza iz šume na cestu, pomoć pri usmjerenom obaranju stabala, izrada prijelaza, privlačenje na pomoćnom stovarištu plaćeni su po vremenu.
Spomenuti traktor ostvario je 81 sat po vremenu (7\%). Imao je 839 sata zastoja zbog kvara. Potrošio je 4,3 1 po pogonskome satu, ostvario je prosječni učinak $51 \mathrm{~m}^{3} / \mathrm{danu}$, a trošak privlačenja iznosio je $43 \mathrm{kn} / \mathrm{m}^{3}$.

Iskoristivost radnog stroja tijekom godine iznosi $84 \%$ što je vidljivo iz usporedbe planiranih radnih sati 1.440 sati i

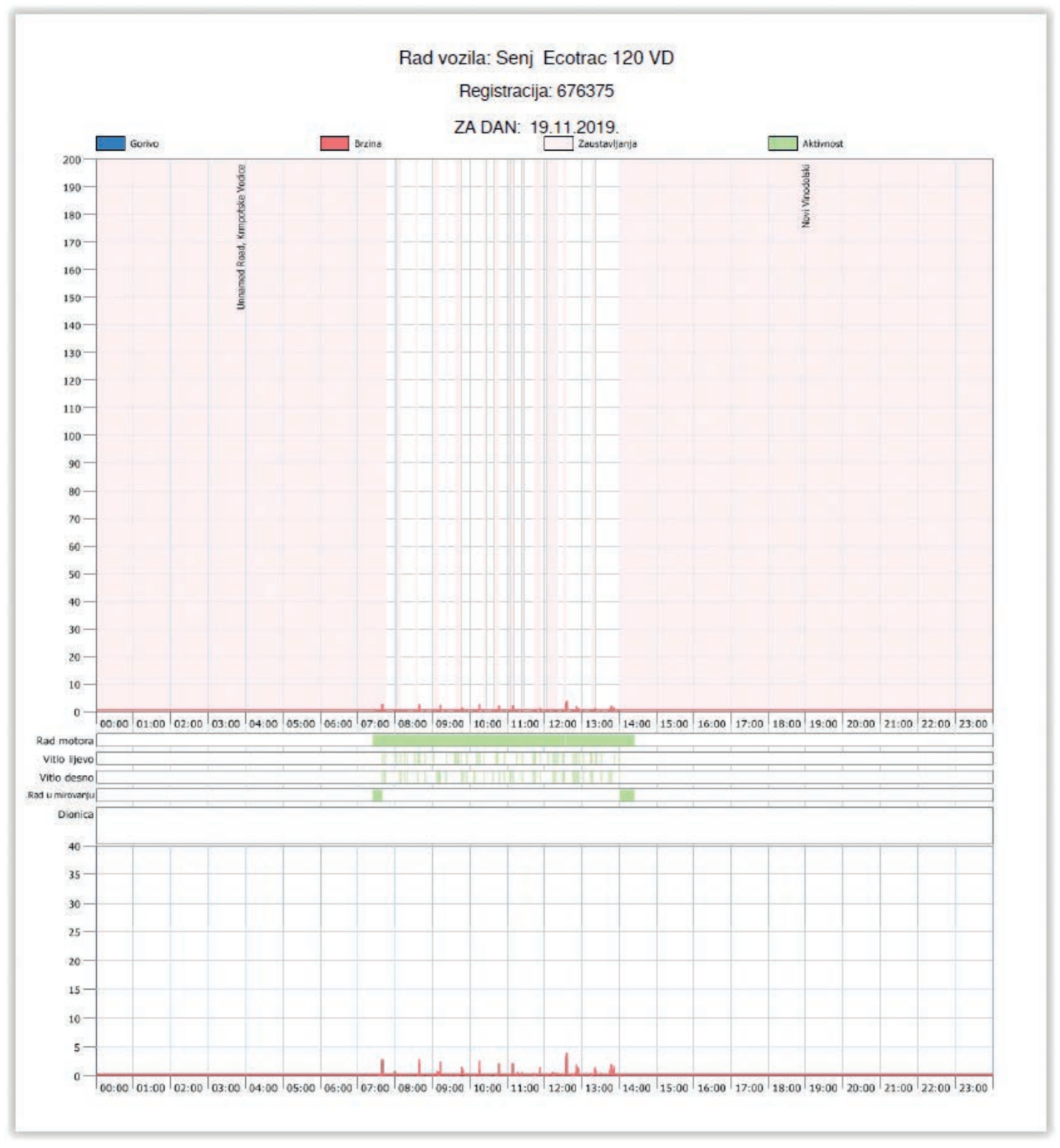

Rad

\begin{tabular}{|c|c|c|c|c|c|}
\hline & Poc̄etak & Kraj & radni sati & Angažirano vrijeme & Udaljenost \\
\hline Vożnja & $07: 47$ & $14: 01$ & $04: 40$ & $06: 14$ & $8 \mathrm{~km}$ \\
\hline Rad motora & $07: 24$ & $14: 25$ & $06: 59$ & $07: 00$ & $8 \mathrm{~km}$ \\
\hline Vițo lijevo & $07: 40$ & $14: 00$ & $00: 13$ & $06: 19$ & $0 \mathrm{~km}$ \\
\hline Vitlo desno & $07: 40$ & $13: 59$ & $00: 13$ & $06: 19$ & $0 \mathrm{~km}$ \\
\hline Rad u mirovaniu & $07: 24$ & $14: 25$ & $00: 40$ & $07: 00$ & $0 \mathrm{~km}$ \\
\hline
\end{tabular}

Slika 4 Grafikon i tablica radnog vremena zglobnog šumskog traktora Ecotrak 120 VD, dana 19. studenog 2019. godine Figure 4 Graph and table of work hours for skidder Ecotrack 120 VD on 19. November 2019 
ostvarenih radnih sati 1.215 sati. Planirani radni sati određeni su kalkulacijom stroja. Kalkulacija stroja bazirana je na nabavnoj vrijednosti stroja, vijeku trajanja i stopi amortizacije, godišnjim efektivnim radnim satima, materijalnim troškovima stroja (materijali za tekuće održavanje, troškovi goriva, maziva, guma, rezervnih dijelova, usluge tekućeg održavanja koje mogu biti eksterne i interne), stalni troškovi stroja (troškove registracije i tehničkog pregleda, premije osiguranja, naknade za autoceste) te trošak strojara. Godišnji efektivni radni sati u zavisnosti su od kalendara radnih dana, zastojima u proizvodnji zbog vremenskih uvjeta, zastojima zbog kvarova, sezonskih zastoja. Godišnji efektivni radni sati različiti su po skupinama iste tehnologije i u korelaciji su s prosječnim izvršenjima u proteklom razdoblju. Zglobni šumski traktori i adaptirani poljoprivredni traktori planirani su 1.400 efektivnih sati/godišnje. Forvarderi i harvesteri planiranu su 1.936 efektivnih sati/ godišnje jer rade u dvije smjene kada to dozvoljava dnevno svjetlo. Kamioni za prijevoz drvnih sortimenata planirani su 1.896 efektivnih sati/godišnje, a iverači 1.600 efektivnih sati/godišnje.

Analiza radnog vremena važna je za poslovodstvo tvrtke i vlasnika stroja, stoga je neophodno svakodnevno kontrolirati rad stroja. Kontrola radnog vremena vidljiva je iz usporedbe podatka o plaćenim radnim satima po učinku i vremenu (1.215 sati) i pogonskih radnih sati (973 sati), Pogonske sate evidentira aplikacija daljinskog praćenja rada stroja Mobilisis Fleet Management. U projektiranoj normi za zglobni šumski traktor efektivno vrijeme čini $80 \%$ radnog vremena, a dodatno vrijeme $20 \%$. U strukturu dodatnog vremena ulazi pripremno završno vrijeme, prekid za jelo, tehnički prekidi i opravdani prekidi. Radno vrijeme je iskorišteno ako su efektivni radni sati (za navedeni traktor 972 sata, odnosno $80 \%$ ukupnih plaćenih radnih sati) usporedivi s pogonskim satima (za navedeni traktor 973 sata).

Neopravdani i nepotrebni prekidi rada iskazuju se u koloni „Neproduktivni sati“ $i$ iskazuju se u crvenoj boji kada su pogonski sati manji u odnosu na efektivne sate. $U$ slučaju iskazanih neproduktivnih sati, problem rješavaju neposredni organizatori rada na terenu.

Upotrebom Mobilisis Fleet Managementa radno vrijeme možemo detaljno kontrolirati za svakog nositelja troška u odabranom razdoblju. Na slici je prikazan izvještaj o radnom vremenu 19. studenog 2020. godine za zglobni šumski traktor Ecotrak 120 VD u šumariji Senj (slika 4 ).

Iz izvještaja su vidljivi pogonski sati rada motora, sati rada vitla, sati rada u mirovanju te brzina kretanja traktora. Rad u mirovanju odnosi se na rad traktora bez vožnje i aktivnosti strojara. Ovaj podatak evidentira se kada traktor stoji na mjestu duže od 10 minuta, a nema aktivnosti vitla ili vožnje. Iz pregleda je vidljivo da je stroj pokrenut u 7:24, a rad je završio u 14:25. U tijeku dana zabilježena su dva razdoblja kada traktor stoji na mjestu, a nema aktivnosti vitla ili vo-

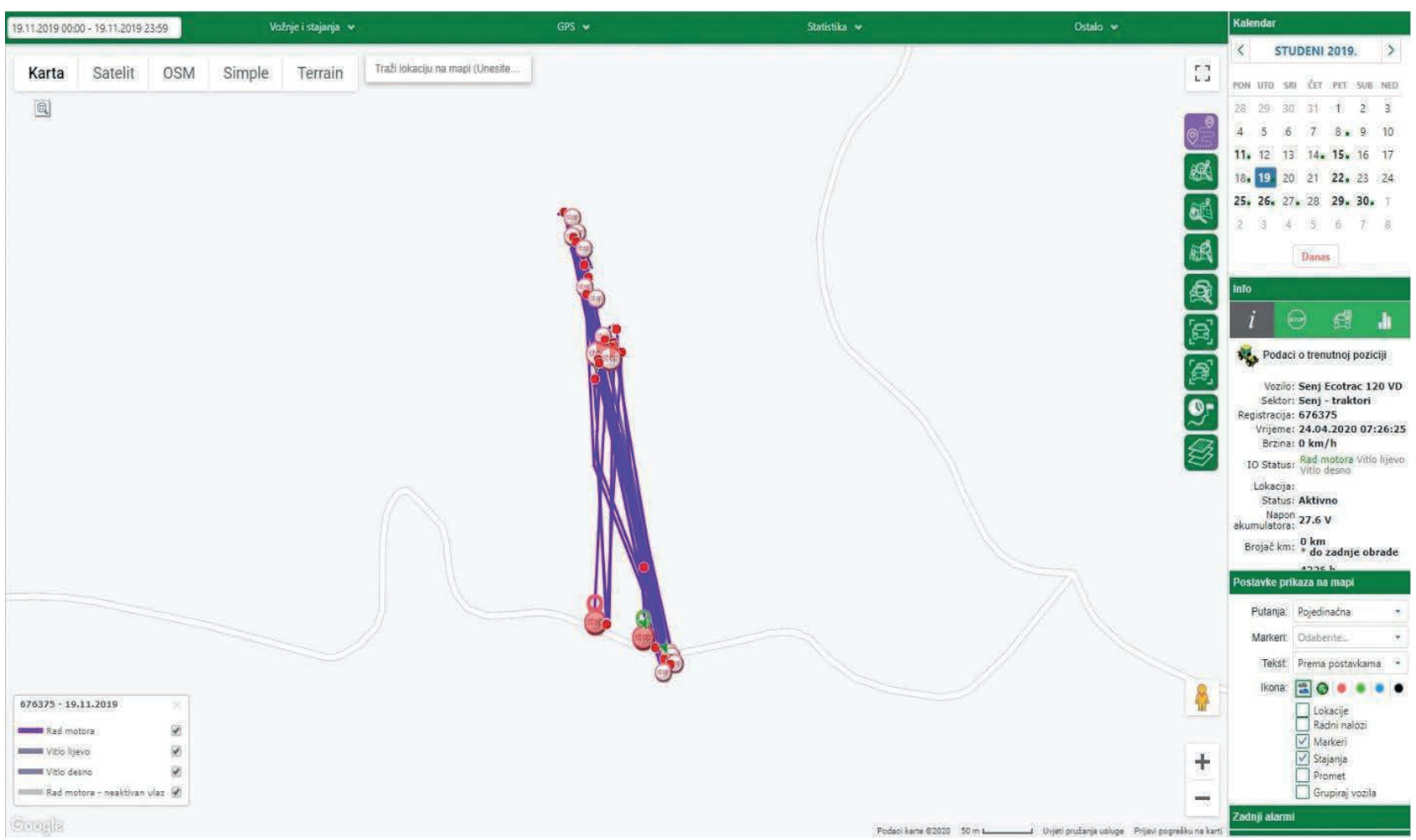

Slika 5. Prikaz vožnji traktora Ecotrak 120VD dana 19. studenoga 2019.

Figure 5. Overview of skidder Ecotrack 120 VD rides on 19. November 2019 
žnje (rad u mirovanju) na početku i na kraju radnog vremena u ukupnom trajanju 40 minuta. Motor traktora dana 19. studenog 2019. godine radio je 7 sati, od čega je u vožnji bio 4 sata 40 minuta. Prikaz kretanja traktora vidljiv je u slici 5.

Web aplikacija HsKPR u izborniku „Analiza“ pruža analitičke izvještaje o pojedinačnim najvećim ostvarenjima pogonskih sati, najvećoj potrošnji goriva, najvećoj ostvarenoj kilometraži.

Dogradnjom web aplikacije kontroling proizvodnje omogućit će se kreiranje izvještaja po zahtjevu korisnika. To znači da će korisnik odabrati parametre koje želi pregledati, a izvještaj će biti prikazan grafički. Primjer je izvještaj o prosječnim učincima $\mathrm{m}^{3} /$ strojo danu za odabranog nositelja troška na razini Hrvatskih šuma, kao i prosječan izravan trošak privlačenja $\mathrm{kn} / \mathrm{m}^{3}$ (slika 6). Iz grafičkog prikaza je vidljivo da kod odabranih zglobnih šumskih traktora najveći učinak od $38 \mathrm{~m}^{3} /$ danu i najniži izravan trošak privlačenja od $64 \mathrm{kn} / \mathrm{m}^{3}$ imaju zglobni traktori Ecotrak 120.

U kategoriji forvardera razlikujemo dvije kategorije, forvardera s iskazanim troškom amortizacije i forvardera starijih od 8 godina koji nemaju trošak amortizacije. Iako prosječni ostvareni učinci izvoženja drvnih sortimenata u ove dvije kategorije iznosi $1 \mathrm{~m}^{3} /$ danu, razlika u cijeni izvoženja je 7 $\mathrm{kn} / \mathrm{m}^{3}$.

Izvještaji o ukupnoj učinkovitosti pojedinih grupa iste tehnologije u odabranom razdoblju kao i izvještaj o iskorištenost planiranih radnih sati pružaju dodatnu analitičku sliku za poslovno upravljanje.

\section{ZAKLJUČAK CONCLUSION}

Operativni Kontroling radnih strojeva pri izvođenju šumskih radova u središte aktivnosti stavlja pokazatelje produktivnosti, profitabilnosti, zastoja, rashoda, prihoda te korištenja radnog vremena. Kontroling kao poslovna funkcija priprema i prezentira izvještaje korisne za aktivnosti planiranja, organiziranja, izdavanja naloga i koordiniranja koji su nadležnost poslovodstva. Lako dostupni izvještaji u web pregledniku, pružaju financijske i naturane pokazatelje.

Prikaz financijskih pokazatelja rashoda po planiranim i izvršenim stavkama goriva, maziva, rezervnih dijelova, guma, uslugama održavanja, troškova registracije, osiguranja, amortizacije i plaća dobra je podloga za ocjenu planiranih rashoda te visine i udjela pojedinih troškova. Dosadašnja

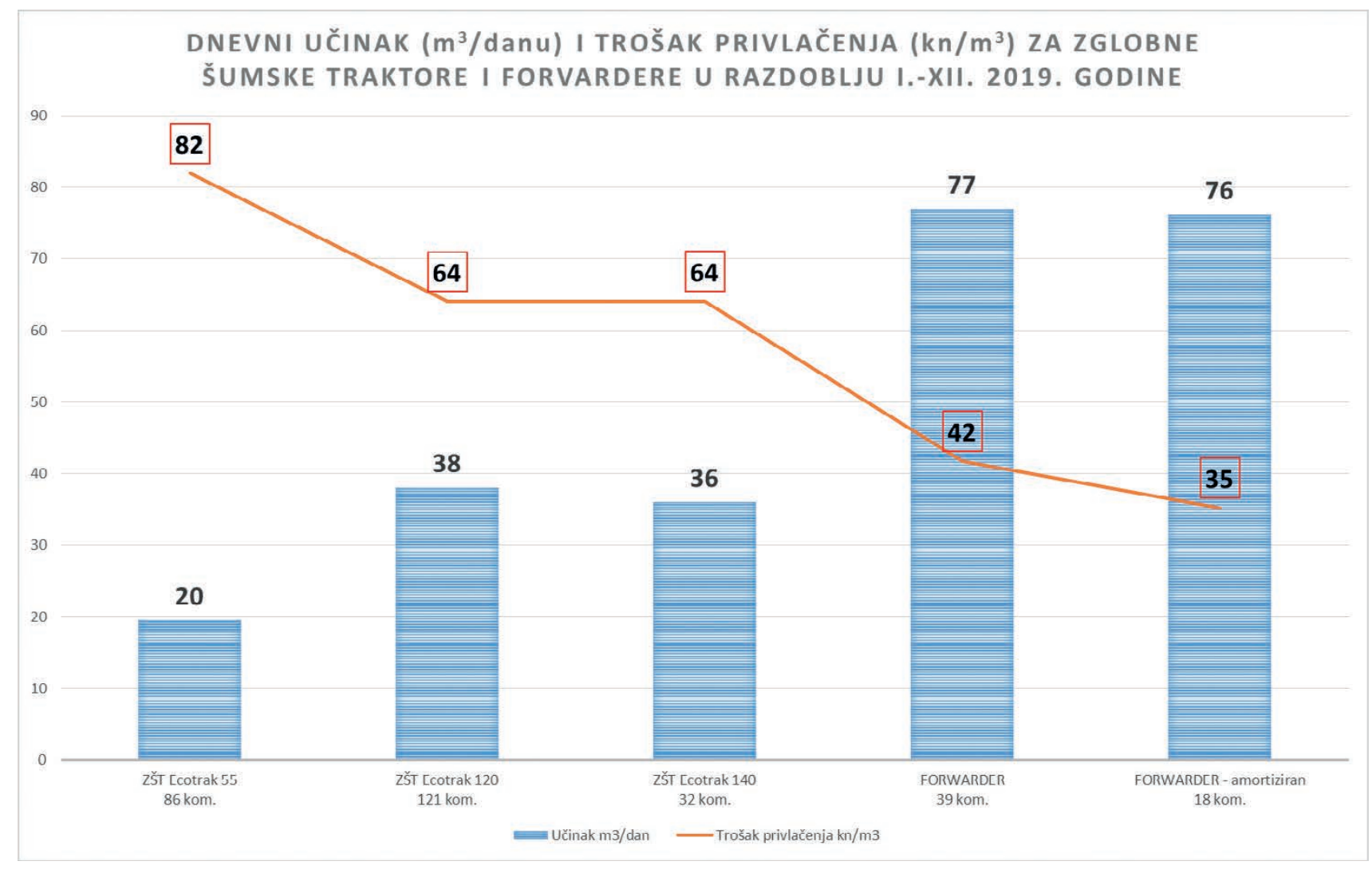

Slika 6 . Učinak po strojo danu $\left(\mathrm{m}^{3} / 8\right.$ sati) i trošak privlačenja $\left(\mathrm{kn} / \mathrm{m}^{3}\right)$ za zglobne šumske traktore Ecotrak 55, Ecotrak 120VD, Ecotrak $140 \mathrm{VD}$ i trošak izvoženja za forvardere i amortizirane forvardere

Figure 6 Machine-day efficiency (m3/8 hours) and skidding cost (kn/m3) for Ecotrak 55, Ecotrak 120VD, Ecotrak 120VD, Ecotrak 140VD and Ecotrak 140VD skidders and and forwarding costs for forwarders and forwarders with depreciated value 
upravljačka kontrola potrošnje goriva rezultirala je uštedom 15 do $20 \%$.

Kontrola naturalnih pokazatelja iskazana u ukupnim izvršenim $\mathrm{m}^{3}$, izvršenim $\mathrm{m}^{3}$ po danu, potrošnji goriva litara po radnom satu i litara po pogonskom satu u usporedbi s istim razdobljem za prethodnu godinu daje realnu sliku produktivnosti u zadanom vremenu.

Izbor najekonomičnijih i najproduktivnijih strojeva za određene tehnologije proizvodnje temeljem pokazatelja o učincima i troškovima rada, dobar su preduvjet za organiziranje proizvodnje i optimizaciju poslovnih procesa.

Donošenje odluka o rashodovanju i nabavi novih strojeva temelji se na utrošcima rezervnih dijelova i troškovima održavanja, odnosno strukturi i količini zastoja te ostvarenim direktnim rashodima i prihodima stroja. Kontrola korištenje radnog vremena spada u obveze rukovodećeg osoblja, a informacije o neproduktivnim satima i praznome hodu podloga su za korekcije u kontroli radnog vremena.

Za uspješno koordiniranje aktivnosti rukovođenja i donošenja poslovnih odluka, neophodno je definirati obveze nižeg, srednjeg i višeg rukovodstva u korištenju kontroling izvještaja i informacija iz web aplikacije HsKPR. Kontroling izvještaji dobra su podloga za ocjenu uspješnosti poslovodstva, a samim time i za objektivno nagrađivanje zaposlenika.

\section{Zahvala - Acknowledgements}

Projekt operativnog kontrolinga u Hrvatske šume d.o.o. implementirali su: Ivica Milković, Krešimir Žagar, Tatjana Klarić, Veljko Kovačević, Nenad Stanišić, Đuro Jendrijev, Damir Klobučar, Boris Romanić, Zvonimir Mišić, Vlado Đurašin.

\section{LITERATURA}

\section{REFERENCES}

- Luković T., Lebefrom U., 2014., CONTROLLING Planom do cilja, 3. str., Sveučilište u Dubrovniku

- Blazek A., Doyle A., Eiselmayer K., 2014., Kontroling i kontroler, 12. str., Kontroling Kognosko d.o.o., Zagreb

- Drljača M.,2004., Izrada financijskog plana i investicijski prioriteti, 74-82 str., Oskar d.o.o Centar za razvoj i kvalitetu, Zagreb

- Medved, M., Ogris, N., Klun, J., Košir, B., Vončina, R., 2005: Calendar Time and Work Performance of Syncrofalke Cable Cranes in the Tolminsko Region. Zbornik gozdarstva in lesarstva 77: 113-142.

- Osmanagić Bedenik, N., Realnost kontrolinga u Hrvatskoj, Zbornik Ekonomskog fakulteta u Zagrebu, godina 1, broj 1, 2003.

- Kuric D., 2010., Istraživanje obilježja kontrolinga u državnim šumarskim poduzećima, Magisterij, Ekonomski fakultet u Zagrebu

\section{SUMMARY}

Controlling of machinery in performing forest works represents a development of business management systems, supervision of working time of machinery and vehicles and analysis of data collected as a basis for making business decisions. This system is connected with other informatic systems (of different business purposes) used in Croatian forests ltd., company that manages state owned forests in Croatia. Financial and non-financial reports shown apply primarily to machinery used in forestry and represent a modern business model of management in operative forestry.

The main instrument of work machinery controlling is web application HsKPR. The application is a control mechanism for activity tracking according to the cost center by each work machine/vehicle in service of mechanisation, construction and personal transportation. Each work machine is treated as a cost and income centre, while each vehicle is treated as a cost centre. The application provides information about planned and realized income, expenditure and profit of a work machine. Expenditure represents machine usability costs, expenses for fuel, oil, spare parts, tires, internal and external maintenance services, amortization, machinist salary expenses. In addition to financial reports on income, expenditure and profit, the application provides non-financial indicators of productivity, operational hours, utilization of working hours, fuel consumption, idle motion and delays. Particularly useful is expense information on machine-day costs and costs realized by the measuring unit $\mathrm{kn} / \mathrm{m} 3$.

Financial and non-financial reports are available at the level of cost and income centre, group cost and income centre and the profit centre. Group cost and income centers are work machines of the same technology, i.e. skidders, forwarders and cable cranes. Profit center is a mechanization activity with sub-activities of skidding, transportation and other work assets, as well as construction activity with sub-activities of work machinery and transportation. All these reports are also available on three organizational levels: forest station, i.e. work unit, forest management centre and company level.

Controlling reports provide basis for managerial decisions, alarm signals for significant unfavorable differences between planned and realized indicators, basis for discovering the reasons for deviations from planned tasks, as well as basis for prescribing necessary activities leading to the planned outcomes.

KEY WORDS: controlling, forest machinery, planning and analysing, management 